\title{
C. Wright Mills, Power and the Power Elites - A Reappraisal
}

\section{Introduction}

Mills can be conceived as a Socratic figure (Casanova, 1964; Barratt,2011a) seeking to caution American citizens of the 1940s and 1950s on the dangers of their era. As an engaged intellectual, Mills highlighted the existence of a new distribution of power associated with the elites of business, politics and the military in an era in which, as he saw it, Americans had become increasingly politically apathetic and inattentive to the forces that shaped their fate. Questions of power were the focus of Mills's interests in his earliest work (Mills,1939). Reliant at this early stage on Mead (1934/1999) for his conception of the ways in which the inner life and conduct of the human subject was shaped through symbolic interplay with others, Mills viewed pragmatism as insufficiently sensitive to the institutional contexts and power dimensions of such processes. But it was during the years of the Second World War that Mills began to refine and develop his analysis. Seeking to refine an inchoate sense of change in American society, Mills's explorations of power suggest an array of intellectual influences. Borrowing from Max Weber, Mills conceived power as the realisation of the will even if this entails the resistance of others (Gerth and Mills, 1967). Mills assumed any society to be divided into distinct, but interconnected institutional orders, raising the question of the distribution of power both within and between those orders. Sympathetic to Marxism, Mills nonetheless sought to de privilege the role of the economic, insisting on the diversity of the 'means of power' and highlighting the significance of bureaucratic, military and political forces. Mills's analysis, as we will see, revealed both the concentration and coordination of power as distinctive trends in this era. Increasingly monopolistic in business organization, centralised in the processes of political decision making and with an expanding military, the fate of American citizens was increasingly determined by powerful and remote forces. And yet, as we will see, Mills never entirely abandoned the possibility of an enhanced form of democracy in the United States. 
Today there are signs of a revival of interest in Mills's analysis of power and elites in organization and management studies. Kerr and Robinson (2012), for example, praise the Power Elite (Mills, 1956/2009) as a classic, a considered engagement with the phenomena of elites that unjustly became unfashionable in the 1960s. Increasingly, as we will highlight, efforts are being made to delineate the new elite formations of our own time, drawing inspiration from Mills (Murphy,2006; McLean et al, 2010; Bowman et al, 2013; Barratt, 2013; Godfrey et al, 2013; Zald et al, 2010). Mills, nevertheless, remains a contentious figure. For some as we will see, it would seem that we would have little to lose by forgetting Mills (Burawoy, 2008). Recent commentators have, we would suggest, shown little interest in the intellectual, social or political context of Mills's analysis. We share with others a belief that a deeper sense of historical context is required when we borrow from the history of management studies (Booth and Rowlinson, 2006; Jacques,2006; Down,2001)). This paper explores the development of Mills's thinking about the elites and dominant forces of his time in the period between the early 1940s and the mid 1950s. Foregrounding Mills's various intellectual debts, we seek to emphasize the political imagination at work in Mills's project as well as the more familiar sociological one (Mills, 1959/2000), as Mills seeks to clarify the 'moral questions' at stake in a particular state of affairs whilst also assessing 'strategic points of intervention' (Mills, 1959/2000). Accordingly, we consider Mills's attempt to forge an ethico - political stance in rapidly changing conditions. Reflecting critically on contemporary readings of Mills, we reflect further on what we might take from him today in our own time.

\section{The 'sophisticated conservatives' and the leaders of labour}

The first intimation of the configuration of power relations that Mills would later term the 'power elite' appeared in the early 1940s as he sought to refine an understanding of developments in the American political economy during these years (Mills, 1942/1963). Mills's response to the growing importance of the State, business and the military should be understood in the context of what one writer has called one of the most 'extraordinary cultural transfers of modern history' (McClay, 1994, p.194): the arrival in the United States in the 1930s and 1940s of a significant number of German speaking intellectuals. If Mills's neo Weberian understanding of power, social structure and stratification was shaped by his association with Hans Gerth (Gerth and Mills, 1948/ 1974), it would be another of the German émigré intellectuals 
that would influence his understanding of a particular formation of power relations in American society.

In Behemoth, Franz Neumann (1942/1966) - differing from the orthodox Frankfurt school view of Germany as a system of state capitalism (Pollock, 1941) - presented the Nazi regime as a collaboration of four political blocs: the Nazi party, the state bureaucracy, the military and heavy industry. Given that each bloc possessed its own system of rule formation and enforcement, the regime should be considered a "non State' (Neumann, 1942, p.xiii) without effective coordination, lacking in any framework of public law and arbitrary in its operation. Yet notwithstanding their institutional autonomy, a commonality of interests and aims gave the blocs cohesion in their operation. War had brought prestige to the military, glory to the Nazis and high profits to business, as the productive power of monopolistic German business became a pillar of the Third Reich and as business leaders enjoyed the spoils of conquest. The blocs ultimately coalesced in pursuit of a common aim: a continual preparation for and maintenance of imperialist war (Neumann, 1942, p.174). Militarisation, as Mills emphasized in his review (Mills, 1942/ 1963), had provided a solution to intractable problems: the economic slump and unemployment of the 1930s. The conclusion that Mills drew from his reading of Neumann was that rather than assuming a relation of absolute difference between the United States and Nazi Germany, Americans might consider certain resemblances between the two societies. Neumann's account of the German system of interlocking elites captured a broader drift in international capitalism - suggesting not only important aspects of the American political economy during war time but the harsh outline of a possible future (Mills,1942/1963, p.177).

Mills (1948/2001) returned to the same theme in his early study of the American labour movement and its leaders. Capturing the predicament of the leaders of labour required an attention to actors in an institutional and social setting, the forces that shaped their activity and influenced their space for manoeuvre: not only the bargaining ploys and practices of business leaders or the expectations of union members, but the mass public and the educated 'publics' - groupings of politically alert actors reflecting different shades of political opinion actively involved in discussing and organising in the public domain. Mills presented a picture of a 
generally conservative and defensive labour leadership, guided by long standing traditions of business unionism, a membership with largely pecuniary interests and a mass public generally hostile to the leaders. Crucially, political debate was increasingly informed by those forces that Mills now termed the 'sophisticated conservatives': an alliance of elite forces that threatened the interests of labour - the true agents of decision and the most dangerous political forces of the time, as he saw it.

Mills's analysis reflected changes in the American political economy that had begun in the 1930s. An alliance of sections of business and the political classes had developed to facilitate the administration of the New Deal (Lichtenstein,1982). The leaders of labour joined this alliance in a subordinate role assisting in the formulation of codes of fair competition under the National Industrial Recovery Act of 1933. The war years saw business and labour collaborating in the administration. During 1941, Sidney Hillman of the CIO played a key role in the Office of Production Management, led by William Knudsen of General Motors, planning the mobilisation of resources. After January 1942, responsibility for the war time planning of production lay with the War Production Board (WPB), controlled by prominent business leaders, providing crucial support to a military strategy based heavily on supremacy in air power (Milward,1977). But labour representatives took up positions in the tripartite National War Labour Board (NWLB), setting wage levels and arbitrating in labour management disputes and in the administration of the system of price control and rationing (Lichtenstein,1982).

In the aftermath of war, as Mills saw it, labour unions were vulnerable to the political manoeuvres of the sophisticated conservatives, an alliance of sections of business, the political classes and the military that favoured the maintenance of collaborative relations with labour. The conservatives sought to promote a narrow collective bargaining agenda, offering union recognition and economic concessions in return for the active cooperation of their leaders in reinforcing management aims and suppressing labour rank and file dissent. Conservatives of this type sought to disguise their ambition to stabilise a particular and unequal distribution of power. The future, according to Mills, held out the prospect of further dangers. The cooperation of labour 
was now sought as a necessary element in fresh plans for the American economy: the building of a corporate 'garrison state' (Mills,1948/2001, p.233).

Mills's central problem with the United States in this era related to a state of affairs that undermined democracy, involving an unhealthy integration of such powerful political, business and military forces excluding the wider public and holding out the prospect of a dangerous war economy in peace time. At the same time, the creative intelligence of American citizens was constrained by this configuration of power relations. In this connection, Mills characterised the leaders of American labour as largely devoid of political will and imagination. Yet at this stage, the hope of an alternative to the circumstances that he outlined had not been entirely extinguished. Throughout this study, there are intimations of the potential of the rank and file and elements of the leadership of the CIO - particularly the Auto Workers Union. In part, Mills's optimism, reflected the influence of the political circles in which he moved at the time (Wald, 1987). Mills evidently lacked the Marxist sectarian tendencies of his associates among those he termed the radical left. But he shared their interest in building a non communist left. Also shared with the radical Trotskyist left was a belief in the tendencies of capitalism to catastrophic economic crisis and a faith in the political potential of the working class. With the impending crisis Mills envisaged the prospect of class polarisation and a radicalisation of the labour rank and file. 'Slump', he argued, would make 'the rank and file show its muscle' (Mills, 1948/2001, p.67). The sophisticated conservatives, with their strategies for the political economy, might well win out in these crisis conditions. Yet labour too, Mills believed, strengthened by its radical membership and by independent intellectuals of the kind employed by the UAW, also stood some chance of prevailing.

For the benefit of a political situation that Mills believed, to a degree at least, to be still open to influence he elaborated a possible alternative future for the United States. In the 1930s, Mills praised those citizens who possessed 'the imagination and intelligence to formulate their own codes...the courage and stamina to live their own lives in spite of social pressure' (Mills,2000,p.34). Now he wrote of the need to induce a capacity for 'initiative and self reliance' (Mills,1948/2001,p.264) in the union membership. The development of a 'vision' for labour implied the constitution of an organization capable of seeing 'with a hundred eyes..... elaborating what might 
be done about it with a hundred minds and stating ....all the probable consequences of each possible move' (Mills,1948/2001,p.284). Mills imagined the possibility that politics would become so much part of the way of life of the American worker, of daily work and social routine 'that political alertness would be part of his human being' (Mills, 1948/2001,p.269).

Though Mills believed John Dewey to be guilty of nostalgia for his belief that democracy should begin 'at home' in the local community and for his insensitivity to modern divisions of class and power (Mills,1966), as others have argued (Tilman,1984), there are echoes of Dewey's political ideals in Mills's formulations at this time. Effective freedom required the ability to contribute actively and intelligently to the collective direction of all social institutions which affected personal existence including the work place. Both Mills and Dewey associated democracy with the enlargement of human character. The self was enhanced by the capacity to determine purpose and desire in all the relations of life. In this respect both Mills and Dewey gave a distinctive democratic inflection to the Emersonian ideal of the self reliant American (West, 1989) able to compose the aggregate of a character. And ultimately all shared a debt to the ancient ethical ideals that Michel Foucault explored in his final books (Foucault, 1985,1986). The theme of self care or self mastery permeated ancient thought from the Platonic dialogues through to the major texts of the late Stoics but through his reading of the early Plato and Montaigne it was revived by Emerson (1836/2000). An 'ethical life' implied a practical process of self constitution, decision making and action. And for Mills and Dewey, it was under democratic conditions, in an extended and participatory sense, that such an ideal had the potential to flourish.

Other resemblances between Mills and Dewey - linked to a shared dependence on particular resources of political discourse - are evident. Both were ultimately committed to republican and Jeffersonian ideals (Rahe, 1993). Jefferson, following Machiavelli and the Roman republicans, assumed that an active and informed citizenry was the best defence of a democratic polity against inherent tendencies to corruption and excess on the part of those who governed. Dewey and Mills concurred, whilst adding that only under participatory conditions could human creative and critical powers find expression. 
Similarly, in developing a particular ideal of workplace democracy, Mills like Dewey in the 1920s, looked to British socialism: to the Guild Socialism of G. D. H. Cole (1920). The basic ideals of the guild system of democracy in the shop, works and industry were borrowed from Cole. The agency of the unions as a democratic force was required not only in securing control of the shop and works but at the level of the governance of industry and the planning and coordination of the national economy. Nationalisation, nonetheless, remained a vital objective. By such means the public interest in the running of industry could be satisfied. The agency of the State implying a new party of the left - remained vital as a means of achieving a proper balance between prices, wages and the surpluses of individual enterprises. The aim was to guard against the inherent dangers of a producer led form of democracy. And like Cole, Mills imagined a role for the State in enabling the organisation of consumers as a political force (Mills,1948/2001, p.263).

Freedom, for both Mills and Dewey, depended on an array of supporting and enabling conditions - including, especially, the material security of workers and citizens. Freedom was not therefore an abstract principle, but an effective power to act. And in this respect much of the detail of Mills's thinking was shaped by the left Keynesians of the American labour movement (Lichtenstein, 2001). Walter Reuther - the new leader of the UAW after 1946 - was clearly of significance for Mills. Reuther had emerged as leader of the rank and file resistance to the divisive and opaque incentive schemes imposed by the National War Labour Board during the war years (Lichtenstein,1995). For his socialism, Reuther appears to have owed a debt to the socialism of Eugene Debs and the ideal of the cooperative commonwealth of labour (Boyle,1995; Lichtenstein,1995). Reuther's subsequent career can be viewed as a series of attempts to interpret and give substance to the ideal of 'industrial democracy' (Lichtenstein,1995). In 1940 as Director of the UAW's General Motors division, Reuther offered an alternative plan for aviation production in preparation for war, arguing for a new board of control for the industry to include representatives of labour, government and management. Later, in 1945, Reuther elaborated on the possibilities for the new post war political economy, arguing for planning mechanisms at national and industry level. Diverse interests - labour, business, government and agriculture - should play a part in coordinating both prices and production. Such 
ideals can be said to have inspired the dispute at General Motors in 1945/6 as Reuther pursued the ambition of establishing public control of the American economy.

But Mills's view of Reuther was ultimately equivocal. Notwithstanding the radicalism of his proposed changes to the political economy, Reuther's democracy would not have altered authority relations at the point of production. There was a danger, as Mills saw it, that Reuther would fall prey to the reactionary forces of the sophisticated conservatives, an inclination to human engineering (Mills,1948/2001) that could lead the Union astray. What Mills appears to have appreciated most was Reuther's part in bringing a number of significant socialist 'intellectuals' into the Union after his election. Inspiring the more innovative elements in Reuther's thought and political strategy, many of the intellectuals had been students at the union funded Brookwood College (Lichtenstein,1995) and possessed a background in the Socialist party, in the fruitful period of open debate before factional infighting with ultra leftist elements had caused the party's decline (Heale,1990). The Union Research Director, Nat Weinburg, exemplifying the best in the UAW leadership as Mills saw it, spoke of the end of business unionism and a new agenda for advancing the welfare of the community as a whole (Weinburg cited in Mills, 2001, p. 259). The left Keynesians of the UAW, especially Donald Montgomery of the Union's Consumer Office (Lichtenstein,1995), saw income redistribution as the key means for promoting aggregate demand, warding off the possibility of a return to the economic conditions of the 1930s. Then there were the innovations in Union democracy associated with the Education department of Victor Reuther: diverse attempts to foster an informed and vibrant activism in the Union (Reuther,1976).

Mills - as others have emphasized (Geary, 2009) - drew inspiration from the UAW in the post war years. To be sure it was never a question of imitation, more of sources that inspired the political imagination. Positions that Mills ultimately adopted in the study of labour (Mills,1948/2001, pp. 258 - 259), the possibility for the unions to engage in formulating their own plans for industry, were derived from his association with the intellectuals of the UAW. Certain macro economic, redistributive policies a sharply graduated income tax, reduced indirect taxes, higher wages and the control of prices - were no more than outlined and, reflecting his republican convictions, Mills hoped to see a public that would engage in continuous evaluation of these 
policies. Yet writing in the later 1940s (Mills,1948/2001) Mills was still encouraged by new thinking among elements of labour.

\section{The Power Elite}

By the final years of the 1940s Mills's disillusionment with labour had grown. Their moment, as he saw, it had passed. The problem lay largely in the conservative leadership, increasingly fearful of changing political conditions with the growing influence of the political right and seeking to protect not only bargaining rights but their own newly won status. The labour leadership now focused overwhelmingly on traditional 'business union' issues: wages and job security with few signs of resistance in the rank and file. Mills noted the leaders of labour seeking to enhance their position in the circles of the 'power elite' (Mills, 1954/1963), taking up positions not only in institutions of the federal government but the international agencies set up to administer the Marshall plan. Involvement at the apex of government served to enhance the prestige of the 'self made' new men of power (Mills,1954/1963, p.101). Mills's subsequent investigations would leave little doubt as to the marginal status of the labour leaders among the elites. And there were wider social changes at stake. Mills now - like many others of the left at this time - increasingly emphasised the conservatism of the American citizenry.

Mills (1956/1999) considered the processes by which the elites were formed, the solidarity and commonalities of value and interest among them. He wrote of the growth and concentration of the means of power at the disposal of those that occupied positions of 'command' in business, the military and the polity. Such means had been greatly expanded by changes over the course of the twentieth century: the emergence of the large scale enterprise, the expansion of the military after 1914 and the growth of central government, associated especially with the period after the New Deal. And the expansion of the powers of those who led these organisations had been accompanied by a pattern of coordination or integration among them. An 'inner circle of political outsiders' now occupied key positions in the administration. Composed of 'members and agents of the corporate rich and the high military in an often uneasy alliance with selected policy makers' (Mills, 1956/1999, p.156), Mills argued that a clique of 'outsiders' had effectively taken over the executive post of administrative command. The consequences for citizens were profound. 
Mills's development of his earlier assessment of the sophisticated conservatives should be understood in the context of changing political conditions of the time. The prestige of the elites of business and the military had been greatly enhanced by their part in the war effort. The international context, the years of the 'cold war' and especially the Korean war, served to consolidate the role of these same forces in the administration. As Mills judged it, a series of related developments signalled that the 'garrison state', which he had anticipated in the 1940s, had now come into being. Representatives of business and the military, with the sanction of politicians, had effectively captured key positions in the executive branch of government. The executive had become the principal site of political decision making, with the legislature as well as the judicial branch relegated to a lower level (Mills, 1999, p.4). Numerous decisions were effectively excluded from legislative or public debate. The military, in particular, now dominated the formation of policy in the fields of international diplomacy and foreign affairs, as well as playing a significant part in the fashioning of economic policy. A 'military metaphysic' (Mills, 1956/1999, p.198) now informed the policy of the State. The permanent expansion of military capability was presented as a means to national security, but served an array of other aims: enhancing the prestige of the military, warding off a return to 'economic slump' and promoting the relentless drive for corporate profitability.

To those who imagined United States as a balanced society, with a freedom of association that allowed the formation of diverse, competing interest groups and a separation of powers between the elements of the State, Mills responded with the image of a social order now dominated by the loosely interconnected cliques of business and the military. Such a regime was at once unaccountable and secretive in its mode of operation. This state of affairs served at once to stifle democracy, political argument and creativity. Americans now knew what it meant to live in a 'military neighbourhood open to catastrophic attack' (Mills,1956/1999, p. 183). They now lived under a state of emergency without foreseeable end (Mills, 1956/1999, p.184). As the United States expanded its capacity to exterminate human life on a global scale through the development and deployment of thermonuclear weapons, its leaders now exposed the world to their 'crackpot definition of reality' ( Mills,1956/1999, p.361). Mills's critique acquired an urgent, even breathless, character. 
Mills's elite was not a ruling class in the way that Marxists imagined. The polity exhibited its own institutional specificity, even if outsiders, associated with the military and business, now occupied central positions in the administration. Mills highlighted the regime of character formation and development through which the elites passed. A 'preparatory' schooling and higher education made possible by access to substantial wealth encouraged similar values and manners among the business elite. Comparable codes were promoted in the disciplinary regimes of West Point and Annapolis. In important respects, the members of the elite were alike: American by birth, predominantly from the cities of the eastern states. A familiarity among them had been born not only through joint experience in the administration - in the planning mechanisms associated with war production or the agencies that emerged with the New Deal - but also through common involvement in trade associations or recreational activities. Though not without their differences, all were ultimately united in pursuit of common interests: the system of private property and the aggrandizement of the military. Mills thus explored the ties of solidarity and cultural homogeneity that made the power elite a social entity. For the elites of America at least, it seemed that the concept of 'class consciousness' had relevance (Mills, 1956/1999, p.283).

Yet these developments took place largely behind the back of the American citizenry. Mills's concept of the 'main drift' suggested the conventional wisdom of the time. Diverse forces were working to promote a particular liberal 'version of reality', a benign image of the forces of power promoting the national interest. The military was now actively involved in a public relations campaign to redefine the reality of international relations in a way that justified the expansion of military capabilities. A combination of public relations and the use of the doctrine of 'official secrets' undermined reasoned political debate, enabling the activities of the elites. At the same time, Mills returned to the conditions of the mass society first considered in the earlier White Collar (1951/2001). Borrowing from the aestheticians among the émigré intellectuals of the Frankfurt school (McClay, 1994), Mills argued that an atomised, passive and compliant citizenry had developed in the United States, encouraged by the practices of mass mediation. To this could be added the effects of alienating work regimes and the expansion and bureaucratisation of political and voluntary organisations. The masses were now moved mainly by culture rather than by reason 
and in such conditions, the possibility of independent thought and popular political action was seriously diminished. The United States had found its own path to the mass society.

Daniel Geary (2009) characterises Mills's investigation of 'the power elite' as a work of disillusioned radicalism: Mills's critique implied a rejection of American society, whilst offering no way out from the predicament he identifed. And yet Mills's position is an ambiguous one; there are certainly moments in which he appears to find cause for optimism in the 'private tensions' (Mills,1956/1999, p.314) and 'inarticulate resentments' (ibid) of the American citizenry. The moment of wide ranging democratisation led by the vanguard elements of the labour movement had clearly passed. Yet Mills, in moments of optimism, still imagined the possibility of a new and reinvigorated democracy. Hope lay in the possibility that a fearful and anxious citizenry might be transformed into one more politically alert, willing to submit the dominant forces of the era - now misusing power - to critical scrutiny and responsible influence. Public opinion, Mills argued, existed where people 'who are not in the government of a country claim the right to express political opinions freely and publicly and the right these opinions should influence and determine the policies, personnel and actions of the government' (Mills, 1956/2009, p.309). Once again, the parallels with Dewey (1927) are evident in the Jeffersonian ideal of a politically alert and active citizenry acting as a sure defence of freedom. In both Mills and Dewey a version of American political history - first systematised by such writers as Daniel Webster, Jared Sparks and Alexis de Tocqeville in the early decades of the nineteenth century (see Gustafson, 2011) - was assumed. Though modern American republicanism built on Roman precedent and possessed its own distinctive institutions, on this interpretation what was most characteristic of American political life was its dispersed scenes of public debate and deliberation. Countless voluntary, self governing and deliberative bodies pursued diverse charitable, social and political goals.

Mills was fully aware of the fictional nature of this narrative (Mills, 1956/1999, p.303). And modern conditions - including the emergence of large scale political institutions and the diverse forms of expert knowledge on which political authorities relied - set the limits within change might be possible. The aim was to explore the 
possibility of republican ideals at a different historical moment and to intimate certain essential preconditions for the formation of public opinion. Associations of citizens free of state interference, settings in which social actors could practice deliberation with their fellows and, by their combination, experience an enhanced sense of their own political agency, provided one such condition. Such institutions would be positioned between 'the family and the small community' on the one hand and 'the effective units of the power elite' on the other (Mills, 1956/1999, p.309).

Mills envisaged a variety of social and institutional changes if his ideal of creative democracy was to be attained. He offered no definitive programme of reform but rather intimated a set of principles that might be taken up and elaborated by others to enable a community of publics to thrive. In part this was a matter of the inculcation of habits in the citizenry. To work with others for shared ends presupposed that citizens engage in a labour of moral and political reflection and evaluation. Accordingly Mills wrote of the need for adult education as a practice of 'self clarification in the ancient sense' (Mills, 1956/1999, p.318). Supplementing vocational learning, a liberal education would include the development of the skills of controversy with one's self 'which we call thinking' and 'with others that we call debate' (Mills,1956/1999, p.318). Evoking the challenge of what he would later call the 'sociological imagination' (Mills, 1959/2000), it was the task of a liberal education to help individuals to clarify the social sources of their inarticulate personal tensions and grievances by locating them in the social conditions of their existence. Education would thus develop the dispositions of character, both intellectual and moral capacities, which would fit men and women for a new democratic social order. And Mills also looked forward to a type of journalism that would enable the individual to transcend his narrow milieu and 'clarify its private meaning' (Mills, 1956/1999, p.315). Such forces and agents would help to call to account the elites of this era in business and the military.

But a new and enhanced democracy also suggested the need for a more responsible form of government. Displacing the artfulness of the public relations campaign and the manipulation of the doctrine of official secrets, Mills looked forward to a new era based on free dialogue between the governed and those who govern. And responsible politics implied changes in the administration. Mills revealed himself as no simple anti bureaucrat, but an enemy of the 'pseudo - bureaucracy' dominated by the 'political outsiders' of the military and business (Mills, 1956/1999, p.235). The inference was that 
Civil Service reform might comprise one of the objectives of the movement of citizens that Mills desired. The power elite had been made possible in part by the absence of a genuinely independent bureaucracy (Mills, 1956/1999, p. 276). The United States had still to break decisively with the system of 'spoils' popularized under the Presidency of Andrew Jackson whereby, subject to the approval of Senate, appointments to the Civil Service were under the control of the President (Mosher, 1982). As early as the 1870s, reformers in the United States had challenged the inefficiency and corrupt nature of a system that rewarded political supporters, looking to the British reforms of the 1850s (Barratt, 2009) for an example of a fully independent and impartial bureaucracy. For Mills, the Pendleton reforms of 1883 which introduced elements of the British system the ideal of an independent civil service, appointment on merit and a Civil Service Commission - contained a fatal flaw. The President retained powers to classify and declassify positions in the offices of government as Civil Service appointments. In the years of the 'New Deal' political appointments at the highest levels of government and in the newly established agencies grew substantially as Roosevelt sought enhanced creativity and commitment in those charged with administering policy (Rourke, 1992). After 1953 Eisenhower responded to such 'politicization' in the offices of the federal government by increasing the level of patronage. For Mills, what the United States required was an independent bureaucracy effectively above party political pressure and with a genuine career civil service. The dominance of 'outsiders' in the offices of government not only demoralized the lower levels of the Civil Service, damaged recruitment and impaired the knowledge and capability available to the federal government. Mills's defence of bureaucracy as a distinctive life order - characterized by virtues of integrity, impartiality and neutrality enjoying a close affinity with democratic ends - recalled Weber (1994). The impartial bureaucracy of an independent civil service was a praiseworthy thing.

\section{Mills and power today}

For Michael Burawoy (2008), notwithstanding a profession of admiration, it would seem that we have little to gain by remembering Mills today. There is a politically debilitating fatalism and pessimism at the heart of Mills's thesis. The idea of a 'power elite' was quickly assimilated into the American collective consciousness (Burawoy, 2008, p.369) but became an anachronism. Yet this assessment appears excessively dismissive. Elsewhere, as we have noted, there is evidence of Mills inspiring fresh insights into the emerging elite formations of our own era. Examples here include 
accounts of the elites of the British financial sector and the lobbying networks and rationalising discourses which helped to secure control of the regulatory agenda in the late 1990s and early 2000s (Bowman et al, 2013). In Britain, the use of business advisers or the reconfiguration of the offices of government in accordance with the norms of the unitary board of the public limited company afford spaces for representatives of a select business elite to enter the offices of government and play a critical role in the fashioning of policy (Barratt, 2013). Recent administrations in the United States have enhanced the powers of the executive branch of government and the business elite remains dominant in the executive. Members of these business and political elites, Aronowitz (2012) argues, emerge from a similar social milieu to that which Mills described. Others (Godfrey et al, 2013) have highlighted the intimate connections and associations between the state in Britain and the United States and the private military and security industry, now at the centre of attempts to privatise warfare. If the 'permanent war economy' has not disappeared (Aronowitz, 2012), with expenditure on the military amounting to $4.3 \%$ of GDP in the final year of the Bush administration, the private military and security industry becomes a major beneficiary of this investment. Business elites expand their influence in the offices of government as neo - liberal governments, seeking economy and efficiency in the delivery of services to the world stage, turn to outsourcing and partnership arrangements. Others, directly evoking Mills (Murphy, 2006), write of a new global governance regime and its mechanisms of formation. The 'power elite' exported to the world stage is understood to comprise the top bureaucracies of transnational governance institutions, multinational corporation executives and the leaders of national governments

We would suggest a number of commonalities in this post Millsian genre of elite theorising. First, there is a desire to stay close to changing formations of power, to move beyond the familiar themes of the processes of corporate ascent, socialisation and inter organisational advancement - the 'corporate interlocks' - associated with Mills's earlier followers (eg Useem, 1984). These analyses suggest not a unified power elite but a variety of elite formations: multidimensional and evanescent in nature. Particular attention is given to the aims and ambitions of the elites as well as well as the tactics and social practices by which they are pursued. And, more generally, it is assumed that Mills requires critical appraisal, with the aim of this re theorising being to reform and revise rather than to reject. 
Mills is inclined at times, as Burawoy (2008) rightly argues, to talk down to the publics that he seeks to interpolate. Edward Thompson (1963) long ago highlighted the tension in Mills's project between the disposition of the expert and the craftsmen. At his most certain and dogmatic, Mills imagined himself as an agent of truth, enlightening others in the realities of their situation, penetrating false appearance. The expert was ultimately a custodian of the 'interests' of others, revealing the sources of their 'alienation'. Surpassing Mills should mean going beyond the dogmatic reasoning to which he is inclined. It should also involve an acknowledgment that 'interests' are only available to actors by virtue of a practice of discursive formulation (Hindess, 1982).

Mills and those who follow an interest in the formation of corporate elite interlocks are vulnerable to Dennis Wrong's concern that they give insufficient attention to how the elites exercise their power (Wrong, 1956, p.279). Mills exemplifies what Barry Hindess (1996) terms the 'capacity outcome' conception of power: power is assumed to be a capacity or 'possession' of particular agents - in Mills's case mainly by virtue of their positioning in bureaucratic hierarchies and networks. The danger is of circular reasoning (Clegg, Courpasson and Phillips, 2006), with greater power being assumed to prevail over lesser power and power relationships assumed in advance of the analysis of any particular field of human action. How elites compete and vie for position is obscured in this analysis (Reed, 2012). This perspective tends to discourage the examination of the forms of knowledge available to and deployed by elites. Mills had little to say of the think tanks and exclusive political discussion groups that informed the thinking of the elites in his era, just as they do in our own (Domhoff, 2006). In his earliest published work Mills (1939) argued for the detailed study of 'vocabularies of motive' and their social and historical conditions of possibility. A research agenda, derived from a reading of classical pragmatism, was proposed but never fully exploited.

Circular in logic, the perspective on which Mills relied tends to discourage the examination of tactics and instruments of power and their deployment in concrete settings. In this regard, Daniel Bell (1963, p.52) was correct to argue that Mills gave little consideration to the norms, values and, especially, the practices of 'leadership' 
that would give the concept of power greater substance. The centralized power of the business and military elites was seemingly limitless: without scope or medium. And Mills ultimately obscures the dependence of the 'summit' - the elites - on a whole complex of power relations and practices beyond the 'strategic command posts' at lower levels, the minor expertise of the manager or of the consultant and the work of translation and interpretation that they bring to bear in their implementation of elite decisions.

Mills has little sense of the relational quality of power (Clegg and Haugard, 2009). Thus the meaning of the mass media for its audiences required further investigation. He is vulnerable to the charge, as Norman Denzin (1990) argues, of neglecting the detail of the experiences of the 'little people' in his major texts. And as others argue (Geary, 2009) this same inclination was apparent in the neglect of important counter tendencies in this era, developments with the potential to destabilise the dominant forces which he documented. Mills had little to say of those neglected under the New Deal (Hayden,2006): those who still experienced poverty and racial oppression. Neglectful of the politics of race and gender, the notion that Mills might help us to explore 'power in all its dimensions' (Aronowitz, 2012) appears in need of qualification. And, more generally, Mills appears an unreliable guide as a theorist of experience of the experience of relations of force.

As we have seen, accompanying Mills's cynical appraisal of the elites is a different sensibility: a sense of the future as open and unfinished and the outline of an alternative political vision. How might Mills be of relevance to critics today in this respect? His Weberian defence of bureaucracy resonates with positions endorsed by contemporary critics in organisation and management studies (du Gay, 2000; Armbruster and Gebert, 2002; Barratt, 2009). Traces of republicanism, with some resemblance to Mills, can also be discerned (eg Barratt, 2009). Yet perhaps, beyond Mills's particular ethico - political preferences, there is a broader issue at stake. After Mills, the clarification of values and politics becomes a personal task and a challenge, involving an on - going process of reflection and the active cultivation of an identity. 'Moral stakes' are not fixed or given. We have noted that Mills's assessment of the costs of the power elite alters over time: the democratic deficit and the possibility of war intimated in the study of the labour leaders (Mills, 1948/2001) gave way to a 
more urgent, even fearful response as the political moment changes (Mills,1956/1999). The practical meaning of each new set of circumstances required an effort of fresh thinking about implications and dangers. And attention was also required to changing political possibilities and what was possible under different economic, social and political conditions. As the moment of labour passes, Mills finds hope in the possibility of an enhanced form of democracy and especially an informed and autonomous citizenry, holding political actors to account, maintaining effective and responsible leadership.

With Mills, the cultivation of an ethico - political position requires an alertness to the passing moment and a work of composition. Like Dewey, Mills is an inheritor of an array of ethical and political discourses that he adapts selectively and critically. Jeffersonian republicanism, elements borrowed from the history of socialist thought and practice, elements of pagan thought and the practical experience and achievements of the political movements of his era were reshaped and adapted in a distinctive and imaginative way. The example of Mills suggests that, without nostalgic yearning, we might further explore historical experience for suppressed and unrealised political possibilities and how they might be made relevant to the conditions of our own time. Cultivating an ethico - political identity in the style of Mills, demands that we should always be prepared to learn from others, to have our perspective widened or radically altered through listening. It suggests, in particular, that we might continue the exploration of the organisational and 'leadership' practices and ideals of the social movements of our own era that others have recently begun (Sutherland et al, 2013). Perhaps too, after Mills, we might begin to rethink our uses of the concept of power. Mills, as we have seen, was not the libertarian enemy of power that some of his liberal critics imagined (Parsons, 1957). Power was not simply the power of one agent 'over' another, as is commonly assumed in organisational and management studies. Mills reminds us that democratic virtues and capabilities are not natural but must be learnt. Mills, in this guise, would encourage us to think more about the enabling or productive nature of power in our attempts to imagine alternatives - the human capacities, resources and conditions that are required when, for example, we imagine workplaces of self rule and self care (Townley,1994; Barratt,2008). 
The personal labour of fashioning an ethico - political stance is thus an unending one. There are contrasts here, it would seem, with positions adopted by contemporary critics as they debate the political implications of their perspectives. Some, in our view rightly, have challenged the value of the fractious internal disputes and scholarly polemics associated with the field of critical organisation and management studies (Parker, 2002; Gray, 2005; Barratt, 2008). But the argument - as we see it more questionably - can be taken a stage further (Gray, 2005). Critics, it is claimed, should acknowledge their common connection to the political left and seek to advance the reputation and standing of critical scholarship within the business school for collective benefit. A bridgehead in the business school could assist critics to speak authoritatively in the public domain, exposing managerial excesses and abuses, including - perhaps most especially - those of the 'global managerial elites' (Grey,2005). The risk however, is of stifling serious discussion of alternatives - a debate that might put the very meaning of a 'left' response in question. After our reading of Mills, to work with others for shared ends presupposes that we pursue a hard labour of personal political reflection and evaluation.

But there there are tensions in Mills's arguments. For Emerson, James and Dewey in the style of Socrates - an attitude of doubt and an openness to change was to be maintained in matters of belief and value. Discriminating judgements, for both James and Dewey, presupposed a grasp of both the conditions and consequences of a set of convictions. One required a capacity for self criticism and a willingness to put matters to the test of practical experience and open debate. Mills, in principle at least, appeared to take a similar view (Mills, 1959/2000). In practice, however, the position is less clear.

Mills (2000) sought to defend himself from the critics of his own era. He caricatured criticism of his thesis from the left (eg Sweezy, 1956) as bounded by an inadequate but doubtless reassuring - faith in Marxist orthodoxy. To liberals (eg Dahl, 1958) he responded by arguing that he had aimed only to capture a 'drift' or tendency in American society. The liberals judged him by the standard of a conspiracy theory, misreading his central thesis. The elites were bound together in more subtle ways, by cultural homogeneity and ties of solidarity born of a variety of social conditions. Liberals imagined themselves as neutral commentators on social developments 
without realising the value commitments inherent in their interventions. They were unable to recognise the decisive shift towards the permanently militarized state and the diverse powers that sustained this development.

But relevant experience of Mills's favoured ideals were ignored in the study of labour. He failed to address the experiments in guild socialism in both Britain and the United States (Matthews,1971). Mills failed to 'think against' his own positions and to explore dangers and risks. A host of relevant criticism was ignored. There were those critics of the guilds, of its limited forms of worker participation (Flexner,1923), critics who raised the problem of how the powerful or those with an urge to the mastery of others might be restrained (Russell, 1918). Mills forgot Nietzsche's (1968) reflections on the dangers of assuming a human will to good. Mills, at times, was vulnerable to the charge of failing to recognise that the capacities of citizens must depend on social and cultural conditions of training and practice (Parsons,1957). At various points, the political imagination was inclined to excess. As we have seen there are moments in the study of labour, when Mills inclined to images of crisis and overcoming to be led by the forces of the working class, a conception borrowed from the radical left but ultimately recalling biblical sources. This was the position that he would later dismiss as that of the labour metaphysician (Mills, 1962).

\section{Concluding Comment}

Small power, middle levels of power................We have offered here a critical appreciation of Mills's examination of power and the power elites of his era. We have commented also on his continuing attempt to theorise a way out from the predicament he described. In the light of an array of plausible criticism, his fundamental conception of power, his tendency to obscure the voices of marginal subjects, the treatment of actual and possible struggles, Mills - we have suggested is not an unproblematic example. Ultimately perhaps it is at a more general level, in respect of his critical sensibility that Mills is at his most persuasive. As we have seen, Mills works critically with the dowry of concepts that he inherited in forging a perspective on the power dimensions of his era. The elaboration of an ethico political position similarly required an ongoing work of reflection and self criticism, a willingness to be moved by events and by others. In the style of Mills, the critic is one 
who seeks to impose a style or taste on his or her values and politics. Critics of management today allude to the need to avoid lapsing into intellectual dogma (Grey and Willmott, 2005) and Mills can serve as an instructive example. But there is a similar need, we would suggest, in respect of the ethico -political stance of the management critic, to avoid unthinking orthodoxy. Mills, we have suggested here, avoided such tendencies. It is at such moments that he is most deeply persuasive and perhaps inspiring to us today. 


\section{Bibliography}

Alvesson, M. and Willmott, H. (1996) Making Sense of Management, London: Sage.

Alvesson, M. and Willmott,H. (2003) Studying Management Critically, London: Sage.

Aronowitz, S. (2012) Taking it Big, New York: CUP.

Barratt, E. (2011) 'Re-reading C. Wright Mills', Organization 18(5): 707 - 724.

Bell,D (1963) The End of Ideology, New York: Free Press.

Bullert, G. (1983) The Politics of John Dewey, Buffalo New York: Prometheus.

Chafe, W.H. (2003) The Unfinished Journey, New York: Oxford University Press.

Cole, G.D.H. (1917) Self Government in Industry, London: Hutchinson Educational.

Dahl, R.A. (1958) 'A critique of the ruling elite model', American Political review 52(2):463 - 466 .

Denzin, N. (1990) 'On the sociological imagination', The Sociological Quarterly 31(1), pp. 1- 22.

Down, S. (2001a) 'The return of popular social science', Human Relations 54(12), pp. $1639-1662$.

Flexner, J. (1923) 'Some aspects of worker's control', Economica Volume 7 (January), pp. $68-82$. 
Foucault, M. (1980) 'The eye of power' in Gordon, C. (Ed.) Power/Knowledge, Hemel Hempstead: Harvester.

Foucault, M. (1985) The Use of Pleasure, London: Penguin.

Foucault, M. (1986) The Care of the Self, London : Penguin.Geary, D. (2009) Radical Ambition, Berkley, CA: University of California Press.

Gordon, D.M., Edwards, R. and Reich, M. (1982) Segmented Work, Divided Workers, Cambridge: Cambridge University Press.

Grey, C. and Willmott, H. (2005) 'Introduction' in Grey, C. and Willmott, H. (Eds.) Critical Management Studies, Oxford: Oxford University Press.

Hayden, T. (2006) Radical Nomad, New York: Paradigm.

Hindess, B. (1996) Discourses of Power, Blackwell: Oxford.

Hochschild, A. (1983) The Managed Heart, Berkeley: University of California Press.

Jacoby, S.M. (1997) Modern Manors, Princeton, NJ: Princeton University Press.

Jacoby, R. (2002) 'Introduction' in C. Wright Mills, White Collar, Oxford:OUP.

Lichtenstion, N. (1982) Labor's War at Home, Cambridge: Cambridge University Press.

Lowenthal, L. (1961) 'The triumph of mass idols', in L. Lowenthal (Ed.) Literature, Popular Culture and Society, Palo Alto: Pacific Books.

Lowy, M. (1987) 'The romantic and Marxist critique of modern society', Theory and Society 16(6): $891-904$.

Marx, K. (1988) The Economic and Philosophical Manuscripts of 1844, London: Prometheus. 
Matthews, F. (1971) 'The building guilds' in Briggs, A. and Saville, J. (Eds.)

Essays in Labour History, Basingstoke: Macmillan.

McClay, W. (1994) The Masterless, Chapel Hill: University of North Carolina.

Miller, J. (1994) Democracy is in the Streets, Cambridge: Harvard University Press.

Mills, C. Wright (1939) 'Language, logic and culture', American Sociological Review4 (October), pp.670 - 680.

Mills, C. Wright (1942) 'Locating the enemy', Partisan Review Volume 9 (September - October), pp.432 - 437 .

Mills, C. Wright (1959) The Sociological Imagination, Oxford: Oxford University Press.

Mills, C. Wright (1962) The Marxists, New York: Dell.

Mills, C. Wright (1963) Power, Politics and People, Oxford: Oxford University Press.

Mills, C. Wright (1966) Sociology and Pragmatism, New York: Oxford University Press .

Mills, C. Wright (1967) Character and Social Structure, New York: Harcourt Brace and World.

Mills, C. Wright (1999) The Power Elite, Oxford: Oxford University Press.

Mills, C.Wright (2000) Letters and Autobiographical Writings, Berkeley: University of California Press.

Mills, C. Wright (2002) White Collar, Oxford:OUP.

Mills, C. Wright (2001) The New Men of Power, Chicago: University of Illinois Press. 
Milward, A.S. (1977) War, Economy and Society, Berkley: University of California Press.

Minson,J. (1993) Questions of Conduct, Basingstoke: Macmillan.

Mir, R. and Mir, A. (2002) 'The organizational imagination', Organisational Research Methods 5(1), pp.105 -125.

Nietszsche, F. (1968) The Will to Good, New York: Vintage.

Parsons,T. (1957) 'The distribution of power in American society', World Politics 10(1): $123-143$.

Riesman, D. (1952) 'White collar', American Journal of Sociology 57(5): 513- 515.

Russell, B. (1918) Roads to Freedom, London: George Allen and Unwin.

Thompson, E.P. (1963) 'C. Wright Mills: the responsible craftsman', Peace News 1431 (29 November).

Thompson, P. and McHugh, D. (2009) Work Organizations, Basingstoke: Palgrave.

Tilman, R. (1984) C.Wright Mills: A Native Radical and his American Intellectual Roots, University Park, PA: Pennsylvania State University Press.

Tonnies, F. (2011) Community and Society, New York: Dover Publications.

Trotsky, L. (1969) Permanent Revolution and Results and Prospects, New York: Pathfinder.

Wald, A. (1987) The New York Intellectuals, Chapel Hill, NC: University of North Carolina Press. 
Watson,T.J. (2008) 'Work and the sociological imagination', Sociology 43(5), pp. $861-867$.

Wrong, D. (1956) 'Power in American society' Commentary 22 (September): 278 280.

Zieger, R.H. (1995) The CIO, Chapel Hill, CA: University of North Carolina Press. 